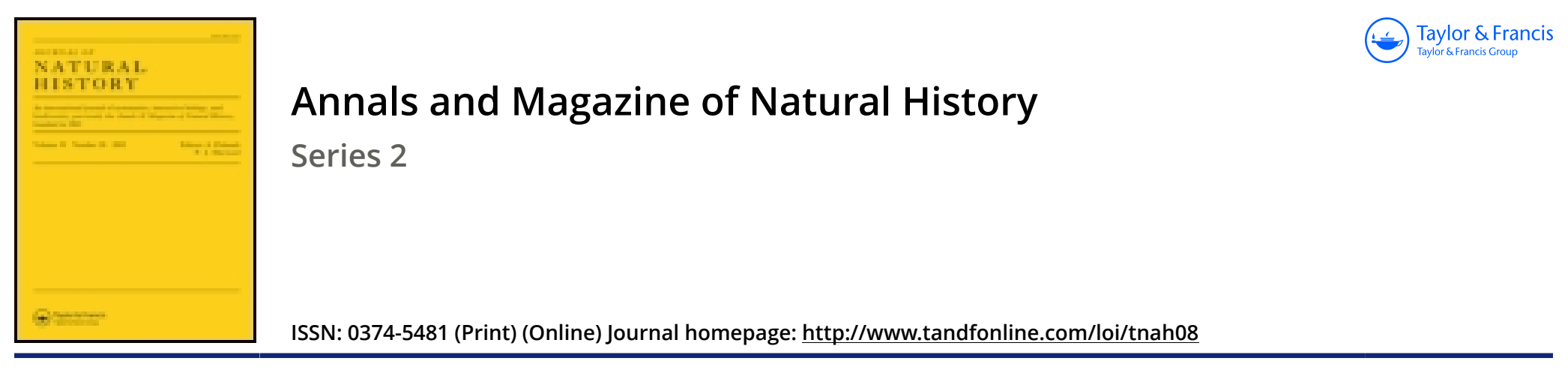

\title{
On the species confounded under the name of Laminaria digitata, with some observations on the genus Laminaria
}

\author{
M.A. Le Jolis
}

To cite this article: M.A. Le Jolis (1855) On the species confounded under the name of Laminaria digitata, with some observations on the genus Laminaria, Annals and Magazine of Natural History, 15:88, 316-318, DOI: 10.1080/037454809495428

To link to this article: http://dx.doi.org/10.1080/037454809495428

曲 Published online: 23 Dec 2009.

Submit your article to this journal $\pi$

Џll Article views: 3

Q View related articles $\sqsubset$ 
white. The tentacles of the first row are pellucid white, with the capitate extremities dead white; the tentacles in the three remaining rows are also pellucid white, in parts tinged faintly with a reddish hue; the capitate extremities have a powdered white edge. The mouth is of a darker yellow than the body.

This species does not appear to change its shape very much, thus differing from the other known British species; the only change I have noticed was that from a state of contraction to one of expansion, from the button shape to nearly a true cylinder, of pretty equal dimensions at both extremities, with a constriction immediately under the crenated margin. It easily adheres by its base to any substance, and may be said to be rather lively, often continuing for some time constantly opening and closing.

It also throws out lobes in the manner of other Actiniada, and these at times completely cover the disk. If touched it instantly contracts, but does not turn sulky, commencing immediately to reopen, which it does very slowly, and this by exserting the tentacles on one quarter of the disk before it begins to exsert those on the other three quarters. The tentacles have not the motion of Actinia or Anthea. I dropped a piece of meat on the disk when opened ; it remained there some little time without being taken into the stomach; after some time the animal wished to rid itself of the meat; it then slowly bent over, and the meat rolled or floated across the tentacles without being impeded by them. When taken this animal was perfectly smooth and free from all foreign substances, such as sand and gravel.

The appearance of this Corynactis reminds me of a coronet, the heads of the outer row of tentacles bearing a resemblance to the balls on the edge of the coronet, and this more so than in either C.viridis or C. Allmannii; and I should have proposed the specific name of coronalis, did it not partly apply to the other species.

Corynactis heterocer a, it will have been seen by the description, differs very materially from the other British species, in the form of the tentacles, the colour, the superior size, the coriaceous texture, its general immutability of form, and in having no foreign substance attached to the epidermis when caught, as in C. Allmarnii. I have named it heterocera in reference to its most prominent distinction from the other species in its differently shaped tentacles.

Hab. Dredged in Weymouth Bay, in 8 fathoms of water, on a gravelly bottom, Sept. 10, 1853.-P̈Proc. Zool. Soc. Nov. 8, 1853.

On the Species confounded under the name of Laminaria digitata, with some Observations on the genas Lamiuaria.

By M. A. Le Jokis.

The author has studied for several years the structure and derelopment of the various forms of the so-called Laminaria digitata growing in the neighbourhood of Cherbourg. He states that his observations agree with those of Clouston made at the Orkneys, and considers that, instead of a single species as admitted by most moderu 
algologists, or several as described by some authors, there are in reality two distinct species, commonly known under the name of $L a$ minaria digitata.

In the tissues of one of these plants, the symplocenchyma predominates, in the other the merenchyma; the stalk of the former also presents concentric rings and muciferous canals, of which the other is completely destitute. The muciferous canals which are wanting in the stems of many Laminaria exist in their fronds, and the author considers that these organs exist normally in the tribe of Laminariacece, and are more or less developed in all parts of those plants which are covered with mucilage.

The vegetation of the two species is very different, and the details which have been given as to the singular manner in which Laminaria digitata renews its fronds, only applies to one species. In the first species the stem is perennial, and regularly increases in length and thickness every year, forming a new concentric layer at its base, exterior to the old ones, and corresponding with a new whorl of roots which are developed above the others; at the same time a new lamina is formed at the base of the old frond, which being separated from the new frond by a very narrow constriction, at last falls off altogether. These phænomena furnish a means of ascertaining the age of the plant, each concentric layer at the base of the stem, or each row of rootlets, corresponding with the annual production of a new frond. The second species appears to have no such determinate periods of vegetation; the frond grows in a continuous and uniform mamner, the stem presents no concentric layers or superposed whorls of rootlets, and no exact indications of age can be derived from the length or the thickness of the stem.

As all observers, with the exception of Clouston, have confounded the two species under the Linnæan name, the author considers that it would only serve to continue the confusion if this name be applied to either of them; he therefore proposes to retain Edmondstone's name, $L$. Cloustoni, for one species, and to give the other the name of $L$. flexicaulis. He gives the following diagnoses of the two species :-

1. Laminaria Cloustoni. L. fibris radicalibus verticillatim radiatimque dispositis, stipite erecto rigido cylindrico rugoso, ad basin valde incrassato, versus apicem sensim attenuato, in laminam multifidam abrupte expanso.

2. Laminaria flexicaulis. $L$. fibris radicalibus inæqualiter dispositis, stipite flexili lævi tereti vel subcompresso, interdum basi subconstricto subfusiformi, sursum complanato, in laminam integram vel multifidam sensim abeunte.

In his observations on the genus Laminaria, the author remarks that the Algæ forming the genus Ilea of Areschoug must be excluded from Laminaria, as they differ from it in structure and fructification. L. brevipes, Ag. and L. dermatodea, Lapyl. also differ in several respects, especially in the form of the root; he places them provisionally in the genus Hatigenia. The genus Hafgygia, formed 
by Kützing for the $L$. digitata, is inadmissible, as muciferous canals exist in many other Alga placed by that author in his genus $L a$ minaria.

The author proposes the following arrangement of the Laminaria :-

\section{Laminaria, Lamx.}

Root fibrous and branched. Stem cylindrical or subcompressed, solid or fistular. Frond flat, ribless, entire or palmate. Cryptostomata wanting.

\section{Section I. Dendroüdece.}

Muciferous canals anastomosing in the cortical layer of the stem, large and scattered in the substance of the froud.

Sp. L. Cloustoni, Edm. (Le Jol.); L. pallida, Grev.

Section II. Saccharina.

Muciferous canals wanting in the stem, small and numerous under the epidermis of the frond.

Sp. L. Aexicaulis, Le Jol.; L. Bongardiana, B. bifurcata, Post. and Rupr.; L. bifida, Gmel.; L. Ruprechtiana, Le Jol. ; L. Chamissoi, Bory ; L. phyllitis, Stackh.; L. saccharina, Linn.; L. latifolia, Ag.; L. Lamourouxii, Bory ; L. longieruris, Lapyl.

Species not seen by the author:--

Of Section I.? L. Bongardiana, P. \& R.; L. himantophylla, P.\& R.

Of Section II.? L. caperata, Lapyl.; L. taniata, P. \& R. ; L. crassifolia, P.\& R.

Haligenia, Decaisne.

Section I. Phyllaria.

H. dermatodea, $H$. triplicata, $H$. brevipes.

Section 11. Saccorhiza.

H. bulbosa, Decaisne.

Comptes Rendus, Feb. 26, 1855, p. 470.

Descriptions of two new Species of Humming Birds, from Peru. By Joнn Govld, F.R.S.

\section{Spathura cissiura.}

General plumage bronzy green; wings purplish brown; four outer tail-feathers purplish steel-black; under surface green, paler on the throat; thighs thickly plumed and of a reddish buff.

Total length, $4 \frac{1}{4}$ inches; bill, $\frac{5}{8}$; wing, $1 \frac{5}{8}$; tail, $2 \frac{3}{8}$.

Hab. Peru.

Remark. - Most nearly allied to Spathura Peruana, but differing from that and all the other members of the genus, in having the outer tail-feathers webbed throughout their entire length, and consequently the spathulate tips less conspicuous. 